\title{
Comparing Surgical Results of Lower Eyelid Retractor Advancement and Retractor Advancement with Lateral Tarsal Strip for Involutional Entropion
}

\author{
Involusyonel Entropionların Cerrahi Tedavisinde Lateral Kantal Askılama ile \\ Kombine Edilen Alt Kapak Retraktör İlerletilmesi Yapılan Olguların Sadece \\ Retraktör İlerletilmesi Yapılan Olgularla Karşılaştırılması
}

\author{
(D) Ayşe Burcu Dirim, (1) İbrahim Çağrı Türker, (1) Ceylan Uslu Doğan, (D) Sümeyra Keleş Yeşiltaş \\ University of Health Sciences Turkey, Şişli Hamidiye Etfal Training and Research Hospital, Clinic of Ophthalmology, İstanbul, Turkey
}

\begin{abstract}
Objective: This study aimed to examine the efficiency of lower eyelid retractor (LER) advancement alone and LER advancement with a lateral tarsal strip (LTS) procedure for involutional lower eyelid entropion treatment.

Methods: In this study, 26 eyelids of 14 patients who underwent LER advancement + LTS (group 1) and 26 eyelids of 24 patients who underwent LER advancement alone (group 2) were retrospectively examined. Patients with or without horizontal laxity were included. The surgery was considered successful with a completely corrected normal eyelid position.

Results: A total of 52 eyelids of 38 patients were included. No relapse was noted in group 1, whereas seven eyelids (26.9\%) in group 2 had a relapse, as noted in the 12-month postoperative follow-up examinations ( $p=0.004)$. One patient in group 2 had ectropion after 2 months. A significant difference was found between the surgical failure rates of the LER advancement + LTS and LER advancement alone.

Conclusion: LER advancement + LTS was entirely successful. The study emphasized the significance of assessing the horizontal eyelid laxity before surgery to avoid recurrence. Those who underwent LER advancement + LTS, rather than LER advancement alone, had higher rates of successful outcomes.
\end{abstract}

Keywords: Lower eyelid, involutional entropion, horizontal eyelid laxity, lower eyelid retractor advancement, tarsal strip surgery

\section{öz}

Amaç: İnvolusyonel entropion cerrahisinde lateral kantal askılama (LKA) ile birlikte alt kapak retraktör ilerletilmesi yapılan olgularla sadece alt kapak retraktör (AKR) ilerletilmesi yapılan olguların karşılaştırılması amaçlandı.

Gereç ve Yöntem: Bu retrospektif çalışmaya Temmuz 2018-Ağustos 2019 tarihleri arasında alt kapak involusyonel entropionu olan 38 hastanın 52 gözü dahil edildi. On dört hastanın 26 gözüne LKA ile birlikte AKR ilerletilmesi (1. grup); 24 hastanın 26 gözüne ise sadece AKR ilerletilmesi yapıldı (2. grup). Yatay kapak gevşekliği olan veya olmayan involusyonel entropiyonlu hastalar çalışmaya dahil edildi. Ameliyat sonrası normal kapak pozisyonunun elde edilmesi klinik başarı olarak kabul edildi. Fonksiyonel başarı kapak malpozisyonuna bağlı epifora, oküler irritasyon gibi şikayetlerin azalması olarak değerlendirildi.

Bulgular: Hastaların 23'ü erkek, 15'i kadın olup yaş ortalaması 74,4 7,6 idi. Birinci grupta nüks görülmezken, ikinci gruptaki 24 hastanın 7'sinde $(\% 26,9)$ ameliyat sonrası 12 aylık takiplerde nüks görüldü. İkinci grupta 1 hastada ameliyattan 2 ay sonra ektropion gelişti. İki grup arasında istatistiksel olarak anlamlı fark saptandı.

Sonuç: İkinci gruptaki hastaların hepsinde cerrahi başarı sağlandı. LKA ile kombine edilen retraktör güçlendirmelerinde başarı oranı sadece retraktör cerrahisi yapılanlara göre daha yüksek bulundu. Çalışmamız nüksü önlemek için ameliyattan önce yatay göz kapağı gevşekliğini değerlendirmenin önemini vurguladı.

Anahtar Kelimeler: Alt göz kapağı, involusyonel entropiyon, horizontal göz kapağı gevşekliği, alt göz kapağı retraktörlerinin ilerletilmesi, tarsal şerit cerrahisi

Address for Correspondence: Ayşe Burcu Dirim, University of Health Sciences Turkey, Şişli Hamidiye Etfal Training and Research Hospital, Clinic of Ophthalmology, İstanbul, Turkey

Phone: +90 5057509559 E-mail: burcu_dirim@hotmail.com ORCID ID: orcid.org/0000-0002-1041-021X

Cite as: Dirim AB, Türker iç, Uslu Doğan C, Keleş Yeşiltaş S. Comparing Surgical Results of Lower Eyelid Retractor Advancement and Retractor Advancement with Lateral Tarsal Strip for Involutional Entropion. Med J Bakirkoy 2021;17:179-183

Received: 07.12.2020

Accepted: 03.09.2021 


\section{INTRODUCTION}

Involutional entropion is an eyelid malposition frequently seen in older people. Epiphora, corneal irritation, and keratitis are also seen due to ocular surface distress resulting from the contact of eyelashes to the ocular surface $(1,2)$. Horizontal and vertical eyelid laxity, tarsal atrophy, senile orbital fat tissue atrophy, preseptal orbicular muscle laxity, and lower eyelid retractor (LER) weakness lead to this condition. The involutional form of this pathology commonly occurs in the lower eyelid; however, the cicatricial form is commonly seen in the upper eyelid (3-5).

Quickert everting sutures are useful to decrease patient distress until the operation, and primary treatments include Jones retractor advancement, Wies repair with or without eyelid shortening, lateral tarsal strip (LTS), and variations of these procedures (6-12). Patients frequently experience recurrence when an accurate technique or an appropriate combination of operations is not performed. Accurate repositioning of LER and sufficient rectification of horizontal eyelid laxity are required during operation to decrease the recurrence possibility (13-20).

This study assessed the efficiency of LER advancement + LTS compared to LER advancement alone for involutional entropion treatment.

\section{METHODS}

This retrospective and comparative study included 52 eyelids of 38 patients with involutional entropion, and it was carried out between July 2018 and August 2019. The study was approved by the Medical Ethics Committee of University of Health Sciences Turkey, Şişli Hamidiye Etfal Training and Research Hospital, İstanbul, Turkey. Horizontal lower eyelid laxity before surgery was assessed using a snap backtest (21). Patients with a follow-up duration of $<12$ months or with a history of any involutional surgery were excluded from the study. The surgery was considered successful with a completely corrected normal eyelid position.

Patients, with or without horizontal lid laxity, were randomly divided into two groups according to the surgical technique. A total of 26 eyelids of 14 patients undergoing LER advancement + LTS (group 1) and 26 eyelids of 24 patients undergoing LER advancement alone (group 2) were analyzed.

\section{Surgical Technique}

All surgeries were carried out under local anesthesia using $2 \mathrm{~mL}$ of 1\% lidocaine with 1:100.000 volume of epinephrine. LER advancement application (Jones procedure): An incision was made on the skin (length $15 \mathrm{~mm}$ ) $3 \mathrm{~mm}$ under the cilia. The layer below the orbicularis oculi muscle was cut through the inferior border of the tarsus of the lower eyelid and dissected toward the cilia to reveal the lower tarsus. The posterior layer of the LER was separated from the conjunctiva. The orbital septum was transversely incised to reveal the sheet-like anterior layer of the LER. Following this, the edge of the posterior layer LER was fixated to the inferior border of the tarsus using three 6.0 doublearmed polyglactin sutures. In addition, a strip of preseptal orbicularis was excised to decrease the inward rotation of the lower eyelid. Later on, the pretarsal orbicularis and the lower edge of the tarsus were affixed at three points. Lastly, the skin was closed using a 6.0 polyglactin suture.

LER advancement + LTS: Following the LER advancement procedure, a lateral canthotomy and inferior cantholisis were carried out first. The tarsal strip preparation was performed by detaching the anterior and posterior lamellae of the lateral lower eyelid and the removal of the anterior lamellae and tarsal conjunctiva through an incision along the inferior tarsal border. The level of horizontal shortening was identified by pulling the strip superolaterally. The tarsal strip was connected to the internal orbital portion of the lateral orbital rim periosteum using 5-0 polypropylene sutures. The orbicularis and skin were then closed up using the 6-0 polyglactin and polypropylene sutures, respectively.

Patients were evaluated on postoperative days 1 and 15 . Follow-up visits were planned on the first, third, sixth, and twelfth months. The operation was considered successful if the normal eyelid position was completely corrected and entropion-related symptoms were absent.

\section{Statistical Analysis}

Mean, standard deviation, median, minimum and maximum value frequency, and percentage were used for descriptive statistics. The distribution of variables was analyzed with the Kolmogorov-Smirnov test. Quantitative data were compared using the Mann-Whitney $U$ test. Data were analyzed using the SPSS software package program version 26.0.

\section{RESULTS}

A total of 38 patients underwent involutional entropion repair during the one-year study period, wherein 23 were males and 15 were females. Group 1 included 26 eyelids of 14 patients, whereas group 2 included 26 eyelids of 24 patients. Both groups were similar in age and sex distribution (Table 1). The mean age was $75.3 \pm 8.2$ years (median 76.5) in group 1 and 74.0 \pm 7.4 in group 2 (Table 2). All operations were carried out by a single surgeon. In 
group 2, seven treated eyelids had a lower eyelid entropion recurrence after 12 months (Table 2), whereas group 1 had no recurrence till the end of the 12-month follow-up period (Figure 1). A statistically significant difference was found between the surgical failure rates in groups 1 and 2 $(p=0.004)$. No serious complications were observed in either group. Postoperative secondary ectropion was observed in a patient, two months after undergoing LER advancement.

\section{DISCUSSION}

Involutional entropion is usually considered to occur with a combination of horizontal laxity, LER dehiscence, and orbicularis override $(22,23)$.

Entropion is corrected using several surgical techniques. Anatomical and functional success can be enhanced with the use of the correct surgical technique or surgical combinations (24). Entropion is frequently caused by multifactorial reasons, thus the primary aim of the operation is to handle the right pathological mechanism. As revealed by previous studies, if at least two pathological mechanisms are corrected, the surgical success increases. At least two of these pathological mechanisms should be corrected to have a higher rate of long-term success (25-27). The recurrence rate ranges from $0 \%$ to $17 \%$, with variable lengths of follow-up. Techniques addressing all three factors responsible for involutional entropion have a lower recurrence rate (0\%-5\%) (28).

Table 1. Demographic characteristics and recurrence rates of patients

\begin{tabular}{|c|c|c|c|c|c|}
\hline & & Min-Max & Median & \multicolumn{2}{|c|}{ Mean \pm SD/n-\% } \\
\hline \multicolumn{2}{|l|}{ Age } & $54.0-89.0$ & 75.5 & \multicolumn{2}{|c|}{$74.4 \pm 7.6$} \\
\hline \multirow{2}{*}{ Gender } & Famale & - & & 15 & $39.5 \%$ \\
\hline & Male & & & 23 & $60.5 \%$ \\
\hline \multirow{2}{*}{ Recurrence } & $(-)$ & & & 45 & $86.5 \%$ \\
\hline & $(+)$ & & & 7 & $13.5 \%$ \\
\hline
\end{tabular}

SD: Standart deviation, Min-Max: Minimum-maximum

Table 2. Demographic characteristics and recurrence rates of the groups

\begin{tabular}{llllll}
\hline & & Group I & Group II & \\
\hline & & Mean \pm SD/n-\% & Median & Mean \pm SD/n-\% & Median \\
\hline Age & & $75.3 \pm 8.2$ & 76.5 & $74.0 \pm 7.4$ & 75.5 \\
\hline \multirow{2}{*}{ Gender } & Famale & 5 & $35.7 \%$ & 10 & $0.544^{\mathrm{m}}$ \\
\cline { 2 - 6 } & Male & 9 & $64.3 \%$ & 14 & $41.7 \%$ \\
Recurrence & $(-)$ & 26 & $100.0 \%$ & 19 & $58.3 \%$ \\
\hline
\end{tabular}

${ }^{m} M a n n-W h i t n e y ~ U$ test, ${ }^{\times 2}$ Chi-square test, SD: Standart deviation
In recent years, loosening the LERs is one of the most important causes of involutional entropion, thus retractor repairs became the most effective approach (Jones procedure). This procedure does not address the issue of orbicularis override; however, the skin incision into the anterior lamellae creates a cicatricial barrier between the lamellae that minimizes the vertical overriding of the preseptal orbicularis (29). Horizontal eyelid laxity is a crucial problem that leads to entropion. LTS is one of the most significant procedures for amending a loose horizontal eyelid (30). A case series of 15 patients who underwent LTS did not show entropion recurrence after an average 13 months of follow-up (31). In another series of 42 eyelids with involutional entropion without horizontal eyelid laxity, 8\% recurrence was reported within 14 months after pentagonal excision (32).

The Wies procedure, with a full-thickness horizontal lid split with everting sutures, is used to turn the lid border outward, with a relatively high rate of recurrence (17\%) (33). Wies reported a recurrence rate of $10 \%$ and a high rate of overcorrection, which is one of the most notable complications of this surgery $(34,35)$.

Everting (Quickert) sutures temporarily solve the problem of entropion. In this surgical technique, scar tissue is created

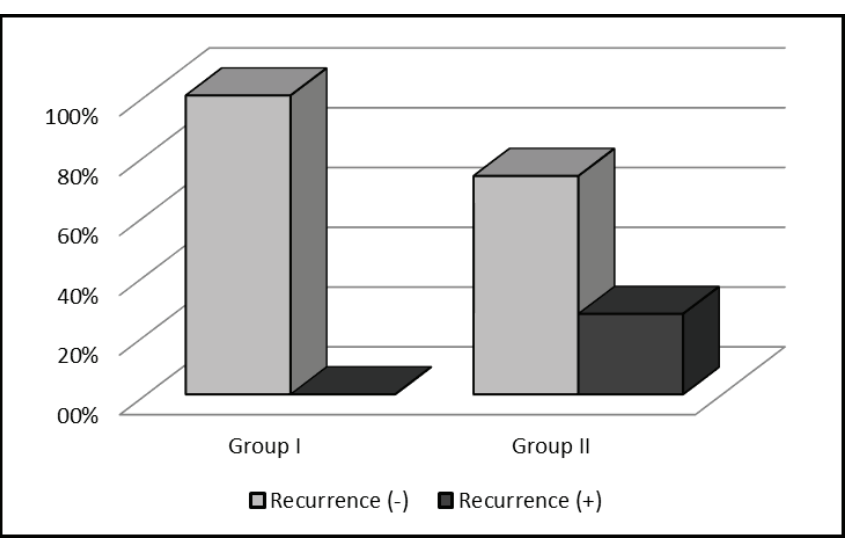

Figure 1. Recurrence rates in the compared groups. 
between the LERs, skin, and orbicularis (36). Jand et al. (37) reported a recurrence rate of $>1 \%$ in six months, which increased to nearly $50 \%$ in two years.

All studies emphasized the significance of eyelid retractor tightening, orbicularis muscle resection, and horizontal eyelid shortening. In studies conducted by Lee et al. (38) and Erb et al. (39) combining tarsal strip with retractor advancement was more successful than retractor advancement alone, with a $96.7 \%$ success rate. Combined surgery is much more effective than LER advancement alone in cases of involutional entropion with horizontal eyelid laxity $(38,39)$. Recently, Scheepers et al. (13) conducted a comparative study that demonstrated the superiority of the combined approach over simple lid retractor tightening with respect to the recurrence rates (38). In addition, Ranno et al. (40) showed that the combination of the Jones procedure and LTS resulted in lower recurrence rates (40).

Our study results were similar to those in the study by Lee et al. (38) Scheepers et al. (13) and Ranno et al. (40) which revealed that LER advancement + LTS was more effective than LER advancement alone for involutional entropion correction, with a lower recurrence rate. The recurrence rate was $0 \%$ in group 1 of our study. The most common complication of transcutaneous LER advancement is ectropion $(41,42)$. One case of ectropion in group 2 was also observed.

\section{Study Limitations}

The limitation of this study is that LTS alone results were not investigated. Future studies comparing LTS alone as an effective method similar to LER advancement are necessary.

\section{CONCLUSION}

In conclusion, combination surgery had higher surgical success and a lower recurrence rate compared to LER advancement alone. Both techniques were safe without serious complications. A combination surgery is recommended to prevent recurrence of involutional lower eyelid entropion regardless of horizontal eyelid laxity.

\section{ETHICS}

Ethics Committee Approval: The study were approved by the University of Health Sciences Turkey, Şişli Hamidiye Etfal Training and Research Hospital of Local Ethics Committee (no: 2909, date: 11.08.2020).

Informed Consent: Informed consent was obtained from the patient.

\section{Authorship Contributions}

Surgical and Medical Practices: A.B.D., I.Ç.T., Concept: A.B.D., I.Ç.T., Design: C.U.D., S.K.Y., Data Collection or
Processing: A.B.D., C.U.D., Analysis or Interpretation: C.U.D., S.K.Y., Literature Search: C.U.D., S.K.Y., Writing: A.B.D., I.Ç.T.

Conflict of Interest: No conflict of interest was declared by the authors.

Financial Disclosure: The authors declared that this study received no financial support.

\section{REFERENCES}

1. Bergstrom R, Czyz CN. Eyelid reconstruction, entropion. Treasure Island, FL: StatPearls; 2018.

2. Benger RS, Musch DC. A comparative study of eyelid parameters in involutional entropion. Ophthalmic Plast Reconstr Surg 1989;5:2817.

3. Jones LT. The anatomy of the lower eyelid and its relation to the cause and cure of entropion. Am J Ophthalmol 1960;49:29-36.

4. Jones LT, Reeh MJ, Tsujimura JK. Senile entropion. Am J Ophthalmol 1963;55:463-9.

5. Collin JR, Rathbun JE. Involutional entropion. A review with evaluation of a procedure. Arch Ophthalmol 1978;96:1058-64.

6. Danks JJ, Rose GE. Involutional lower lid entropion: to shorten or not to shorten? Ophthalmology 1998;105:2065-7.

7. Bashour M, Harvey J. Causes of involutional ectropion and entropion--age-related tarsal changes are the key. Ophthalmic Plast Reconstr Surg 2000;16:131-41.

8. Steel DH, Hoh HB, Harrad RA, Collins CR. Botulinum toxin for the temporary treatment of involutional lower lid entropion: a clinical and morphological study. Eye (Lond) 1997;11:472-5.

9. Quickert $\mathrm{MH}$, Rathbun E. Suture repair of entropion. Arch Ophthalmol 1971;85:304-5.

10. WIES FA. Surgical treatment of entropion. J Int Coll Surg 1954;21:758-60.

11. Jones LT, Reeh MJ, Wobig JL. Senile entropion. A new concept for correction. Am J Ophthalmol 1972;74:327-9.

12. Collin JRO. A Manual of Systematic Eyelid Surgery. 2nd. Edinburgh: Churchill Livingstone; 1989: p. 7-26.

13. Scheepers MA, Singh R, Ng J, Zuercher D, Gibson A, Bunce C, et al. A randomized controlled trial comparing everting sutures with everting sutures and a lateral tarsal strip for involutional entropion. Ophthalmology 2010;117:352-5.

14. Cook T, Lucarelli MJ, Lemke BN, Dortzbach RK. Primary and secondary transconjunctival involutional entropion repair. Ophthalmology 2001;108:989-93.

15. Barnes JA, Bunce C, Olver JM. Simple effective surgery for involutional entropion suitable for the general ophthalmologist. Ophthalmology 2006;113:92-6.

16. Ho SF, Pherwani A, Elsherbiny SM, Reuser T. Lateral tarsal strip and quickert sutures for lower eyelid entropion. Ophthalmic Plast Reconstr Surg 2005;21:345-8.

17. Quist LH. Tarsal strip combined with modified Quickert-Rathbun sutures for involutional entropion. Can J Ophthalmol 2002;37:23844.

18. Rougraff PM, Tse DT, Johnson TE, Feuer W. Involutional entropion repair with fornix sutures and lateral tarsal strip procedure. Ophthalmic Plast Reconstr Surg 2001;17:281-7.

19. Kakizaki H, Zako M, Kinoshita S, Iwaki M. Posterior layer advancement of the lower eyelid retractor in involutional entropion repair. Ophthalmic Plast Reconstr Surg 2007;23:292-5. 
20. Boboridis KG, Bunce C. Interventions for involutional lower lid entropion. Cochrane Database Syst Rev 2011;(12):CD002221.

21. Olver J. Lacrimal assessment. In: Olver J, ed. Colour Atlas of lacrimal surgery. Oxford: Butterworth-Heinemann; 2001: p. 44-7.

22. Vallabhanath $P$, Carter SR. Ectropion and entropion. Curr Opin Ophthalmol 2000;11:345-51.

23. Hintschich C. Correction of entropion and ectropion. Dev Ophthalmol 2008;41:85-102.

24. Shaeffer A. Involutional entropion. In: Smith BC, Della Rocca RC Nesi FA, Lisman RD, eds. Ophthalmic Plastic and Reconstructive Surgery, vol 1. St. Louis: Mosby; 1987; p.546-55.

25. Carroll RP, Allen SE. Combined procedure for repair of involutional entropion. Ophthalmic Plast Reconstr Surg 1991;7:123-7.

26. Wesley RE, Collins JW. Combined procedure for senile entropion. Ophthalmic Surg 1983;14:401-5.

27. Hedin A. Senile entropion - cure rate by retractor tightening and horizontal shortening. Acta Ophthalmol Scand 1997;75:443-6.

28. Nowinski TS. Orbicularis oculi muscle extirpation in a combined procedure for involutional entropion. Ophthalmology 1991;98:1250-6.

29. Rougraff PM, Tse DT, Johnson TE, Feuer W. Involutional entropion repair with fornix sutures and lateral tarsal strip procedure. Ophthalmic Plast Reconstr Surg 2001;17:281-7.

30. Beigi B, Kashkouli MB, Shaw A, Murthy R. Fornix fat prolapse as a sign for involutional entropion. Ophthalmology 2008;115:1608-12.

31. Balaji K, Balaji V, Kummararaj G. The correction of involutional entropion of eyelid by lateral strip procedure. J Surg Tech Case Rep 2010;2:64-6.

32. Tsang S, Yau GS, Lee JW, Chu AT, Yuen CY. Surgical outcome of involutional lower eyelid entropion correction using transcutaneous everting sutures in Chinese patients. Int Ophthalmol 2014;34:8658.
33. Lance SE, Wilkins RB. Involutional entropion: a retrospective analysis of the Wies procedure alone or combined with a horizontal shortening procedure. Ophthalmic Plast Reconstr Surg 1991;7:2737.

34. WIES FA. Surgical treatment of entropion. J Int Coll Surg 1954;21:758-60.

35. Baylis HI, Cies WA, Kamin DF. Overcorrections of the Wies procedure. Trans Ophthalmol Soc U K 1976;96:458-61.

36. Nowinski TS. Entropion. In: Tse DT, editor. Color Atlas of Oculoplastic Surgery. 2nded. Philadelphia (PA): Lippincott Williams \&Wilkins; 2011. p. 44-53.

37. Jang SY, Choi SR, Jang JW, Kim SJ, Choi HS. Long-term surgical outcomes of Quickert sutures for involutional lower eyelid entropion. J Craniomaxillofac Surg 2014;42:1629-31.

38. Lee H, Takahashi Y, Ichinose A, Kakizaki H. Comparison of surgical outcomes between simple posterior layer advancement of lower eyelid retractors and combination with a lateral tarsal strip procedure for involutional entropion in a Japanese population. $\mathrm{Br}$ J Ophthalmol 2014;98:1579-82.

39. Erb MH, Uzcategui N, Dresner SC. Efficacy and complications of the transconjunctival entropion repair for lower eyelid involutional entropion. Ophthalmology 2006;113:2351-6.

40. Ranno S, Sacchi M, Gilardi D, Lembo A, Nucci P. Retractor plication versus retractor plication and lateral tarsal strip for eyelid entropion correction. Eur J Ophthalmol 2014;24:141-6.

41. Chu YC, Yang JW, Tsai YJ, Wu SY, Liao YL, Chu HY. Correction of involutional entropion with retractor redirection. Orbit 2016;35:20711.

42. Nakauchi K, Mimura O. Combination of a modified Hotz procedure with the Jones procedure decreases the recurrence of involutional entropion. Clin Ophthalmol 2012;6:1819-22. 